\title{
Endokannabinoide sistemaren parte-hartzea arratoien garuntxoaren jaio osteko garapenean
}

\author{
(The endocannabinoid system during \\ the postnatal development of the rat cerebellum)
}

\author{
Ianire Buceta, Irantzu Rico-Barrio, Jon Egaña-Huguet, \\ Svein Achicallende, Itziar Terradillos, Nagore Puente, Leire Reguero, \\ Naiara Royo, Itziar Bonilla-Del Río, Aitor Medrano, \\ Juan Mendizabal-Zubiaga, Sonia María Gómez-Urquijo, \\ Almudena Ramos, Inmaculada Gerrikagoitia, Pedro Grandes, \\ Izaskun Elezgarai
}

Neurozientziak Saila, Medikuntza eta Erizaintza Fakultatea, Euskal Herriko Unibertsitatea E-48940, Leioa

ibuceta@hotmail.com

DOI: $10.1387 /$ ekaia.19446

Onartua: 2018-06-13

Laburpena: Endokannabinoide-sistema (EKS) zelulen arteko komunikazio-sistema fisiologiko neuromodulatzaile garrantzitsuenetako bat da, eta helduaroan beraren funtzio ezagunena neurotransmisoreen doikuntza da. Azken urteotako ikerketek, aldiz, funtzio garrantzitsu horrez gain, garapen-prozesuetan ere parte-hartze handia duela erakutsi dute. Izan ere, zenbait artikuluk burmuinaren arauzko enbrioi-garapenerako EKSren beharra agerian utzi dute. Enbrioi-aroko ikerketek muga metodologiko handiak dituzte, eta orain arteko ikerketa gehienak hazkuntza zelularretan egin dira. Halere, burmuineko garuntxoaren kortexean, EKSren adierazpena handia da, eta jaio osteko garapen-prozesu guztiak biltzen ditu: pikor-zelulen morfogenesia, hain zuzen ere. Lan honetan, ultraegitura mailan, EKSren zenbait osagairen kokapena aztertu da; pikor-neuronen garapenaren faseetan baita helduaroan ere. $\mathrm{CB}_{1}$ kannabinoideen hartzailea, eta 2-arakidonil-glizerol (2-AG) endokannabinoidea sintetizatzen eta degradatzen dituzten entzimak - diazilglizerol lipasa (DAGL- $\alpha$ ) eta monoazilglizerol lipasa (MAGL), hurrenez hurren - batera ageri dira hazkuntza- eta migrazio-prozesuetan dauden zuntz paraleloen axoietan jaio osteko garapen goiztiarrean. Konkretuki, $\mathrm{CB}_{1}$ eta DAGL- $\alpha$ zuntz paraleloen mintzean kokatzen dira, eta MAGL, mintzean ez ezik, zitoplasman ere adierazten da. Jaio osteko 12. egunean, zuntz paraleloek Pur- 
I. Buceta, I. Rico, J. Egaña, S. Achicallende, I. Terradillos, N. Puente, L. Reguero, N. Royo, I. Bonilla, A. Medrano, J. Mendizabal, S.M. Gómez, A. Ramos, I. Gerrikagoitia, P. Grandes, I. Elezgarai

kinje neuronen arantza dendritikoekin kontaktu sinaptikoak ezartzen dituztenean, $\mathrm{CB}_{1}$ eta MAGL zuntz horien bukaera sinaptikoan mantenduko dira. $\mathrm{CB}_{1}$ bukaera sinaptiko horien mintzean kokatzen da, eta MAGL, aldiz, mintzaren hurrentasunean ez ezik, zitoplasman ere adierazten da. DAGL- $\alpha$, zuntz paraleloen bukaera sinaptikotik desagertuko da, eta alde postsinaptikoan adieraziko da - hots, Purkinje neuronen arantza dendritikoetan - . EKSn aztertutako 3 osagai horiek batera ageri dira zuntz paraleloetan garapenean zehar, kontaktu sinaptikoak ezarri arte. Horrela, zuntz horiek helduaren ezaugarriak lortzen dituztenean, hartzailea eta degradazio-entzima zuntz paraleloen bukaera sinaptikoan mantenduko dira. Sintesi-entzima, aldiz, axoi-profil horietatik desagertuko da, eta elementu postsinaptikoan adierazten hasiko da - hots, Purkinje neuronen arantza dendritikoetan - . Modu horretan, aztertutako aldi bakoitzean, EKSko osagaien kokapen espezifikoa bistaratu zen. Lortutako emaitzek EKS moldakorra dela eta funtzio desberdinetara egoki daitekeela iradokitzen dute, bere jarduna modu desberdinetan betez. Testuinguru horretan, garuntxoaren garapenean EKSren osagaien kokapen zehatza eta izaera identifikatzea alderdi kritikoa da, haurdun dauden emakumeen eta baita nerabeen kalamu-kontsumoak garunean egitura, funtzio eta portaera mailan eragiten dituen aldaketak ulertzeko. Horrez gain, jakintza hori terapeutikoki erabil daiteke, endokannabinoideen manipulazioak aplikazio klinikoak izan baititzake jaio osteko garapenean eta haurtzaroan gertatzen diren nerbio-sistemako gaixotasunen tratamenduan.

Hitz gakoak: endokannabinoide-sistema, burmuinaren garapena, garuntxoa, zuntz paraleloak, mikroskopia elektronikoa.

\begin{abstract}
The endocannabinoid system (ECS) is widely distributed throughout the organism. This system influences brain development and suppresses neurotransmitter release in the mature brain, thus contributing to brain circuit formation and neural communication. Because of methodological limitations, most investigations focused on the study of the embryo development have been carried out in cell culture. In the central nervous system, the ECS is highly expressed in the cerebellar cortex where it plays a crucial role in the postnatal development of the granule cells. However, little is known about how the precise localization of the components of the ECS takes place during the early postnatal development, which is needed for the correct wiring of the cerebellar circuits. In this study, we used high resolution immunoelectron microscopy to investigate the subcellular localization of the cannabinoid $\mathrm{CB}_{1}$ receptor and the main enzymes for the synthesis and degradation of the endocannabinoid 2-arachidonoyl-glycerol (2-AG), diacylglycerol lipase (DAGL- $\alpha$ ) and monoacylglycerol lipase (MAGL), respectively, in the granule cells during the early postnatal development of the cerebellum. The $\mathrm{CB}_{1}$ receptor, DAGL- $\alpha$ and MAGL were localized at the granule cell axons, the parallel fibers, during granule cell migration and axon elongation occurring at early postnatal age. Moreover, $\mathrm{CB}_{1}$ receptor and DAGL- $\alpha$ immunoparticles were placed in the parallel fiber membranes, while MAGL labeling was at the parallel fiber membranes and cytoplasm. At postnatal day 12, when parallel fibers make already synapses with the Purkinje cell dendritic spines, the $\mathrm{CB}_{1}$ receptor exhibited the typical presynaptic localization in parallel fiber terminal membranes, and MAGL was close to the membrane and in the cytoplasm of the parallel fiber terminals. However, DAGL- $\alpha$ was excluded from the parallel fiber terminals but it was expressed at postsynaptic sites. Altogether, the expression of $\mathrm{CB}_{1}$ receptors, DAGL- $\alpha$, and MAGL in the granule cell parallel fibers starts at early stages of the postnatal development. Later on, the $\mathrm{CB}_{1}$ re-
\end{abstract}


ceptors and MAGL remain in the mature parallel fiber synapses, while DAGL- $\alpha$ disappears from them and switches to the postsynaptic dendritic spines of the Purkinje cells. These structural changes correlate with the functions in which the ECS is involved during postnatal development. Hence, the identification of the specific localization of the components of the ECS in the developing cerebellum is crucial for understanding the structural, functional and behavioral changes taking place in the brain by cannabis consume. Furthermore, this knowledge could be exploited therapeutically as the ECS manipulation might have potential clinical applications in the treatment of brain diseases caused by abnormal development of the brain.

Keywords: endocannabinoid system, brain development, cerebellum, parallel fibres, electron microscopy.

\section{SARRERA}

\subsection{Endokannabinoide-sistema (EKS)}

Kannabinoide-sistema landareek eta animaliek daukaten seinaleztapen-sistema endogeno konplexu bat da. $\Delta^{9}$-tetrahidrocannabinol $\left(\Delta^{9}\right.$-THC) - Cannabis sativa landaretik eratorritako fitokannabinoidea, alegia - kalamua kontsumitzean azaleratzen diren efektu psikotropikoen erantzule nagusietako bat da. Gizakiarengan eta gainerako animaliengan eragina dauka. Izan ere, gizakiok berez daukagun sistema endogenoa landareek daukatenaren oso antzekoa da. Animalien kannabinoide-sistemari endokannabinoide-sistema (EKS) deritzogu. Neuronek, beste organo eta ehunetako zelula ugarik bezala, baldintza fisiologikoetan kannabinoideen hartzaileei espezifikoki lotzen zaizkien molekulak, endokannabinoideak (eKB), ekoizten dituzte. Molekula horiek neuronen mintza osatzen duten fosfolipidoetatik eratorritako lipidoak dira. Horien artean, ezagunenak anandamida (AEA) eta 2-arakidonilglizerola (2-AG) dira. EKB horietariko bakoitzak bere sintesi- eta degradazio-entzimak ditu. Anandamida N-arakidonil-fosfatidiletanolaminaren Fosfolipasa D (NAPE-PLD) entzimak sintetizatzen du [1, 2, 3, 4], eta gantz azidoen amido hidrolasa (FAAH) proteinak degradatzen du (sakontzeko: $[5,6,7]$ ), eta $2-\mathrm{AG}$, berriz, diazilglizerol lipasa (DAGL- $\alpha$ ) entzimak sintetizatzen du [8], eta monoazilglizerol lipasa (MAGL) entzimak degradatzen [9, 10, 11].

Hartzaile endokannabinoide ezagunenak bi dira: $\mathrm{CB}_{1}$ eta $\mathrm{CB}_{2}$. Bi hartzaile horiek, nerbio-sistema zentralean (NSZ), organoetan eta ehun periferikoetan aurkitzen dira, nahiz eta $\mathrm{CB}_{1}$ hartzailea NSZn nabarmen ugariago azaltzen den. EKS, beraz, hauek osatzen dute: kannabidoideen hartzaileek, haien estekatzaile endogeno diren eKB-ek eta horien sintesi- eta degradazio-entzimek, baita eKB-ak erregulatzen dituzten zelula barneko seinaleztapenek ere [12]. 
I. Buceta, I. Rico, J. Egaña, S. Achicallende, I. Terradillos, N. Puente, L. Reguero, N. Royo, I. Bonilla, A. Medrano, J. Mendizabal, S.M. Gómez, A. Ramos, I. Gerrikagoitia, P. Grandes, I. Elezgarai

\subsection{Neuronen garapen-prozesuak}

Neuronek beren berezko morfologia, berariazko ezaugarriak, behin betiko kokapena eta funtzioa lortzeko, zenbait garapen-prozesu jasaten dituzte $[13,14,15,16,17]$. Neuronak haien aitzindari diren zeluletatik sortzen dira. Aitzindari horien berezitasunetariko bat da populazioa handitu dezaketela mekanismo zelular eta molekular desberdinen elkarrekintzaz zelula kopuru egokia lortu arte [14]. Prozesu horri proliferazio deritzo $[14,18]$. Ondoren, eta neurogenesia deritzon prozesuaren bitartez, aitzindari horiek neurona bihurtuko dira $[14,18]$. Horretarako, neurona mota bakoitzaren ezaugarriak adierazteko behar duten informazio osoa bilduko dute [19]. Neurona mota bakoitzaren ezaugarri horiek, lehenik eta behin, beren morfologia gailentzeko darabilte, desberdintzapen deritzon prozesuaren bitartez, beren berariazko funtzioa bete dezaten, gerora $[14,16,18]$. Neuronen desberdintzapenaren lehen urratsa neuritogenesia da; hau da, neuronetan, aurkako polo bi hedatuko dira, zeinek axoi bat eta zenbait dendrita emango dituzten $[14,16,18]$. Bai axoiak eta bai dendritak hazkuntza-prozesuan sartuko dira [20]. Dendriten adarkadurak haziz eta ugarituz joango dira garapenean zehar, beren itura iritsi arte; epealdi horretan, arantza dendritikoak ere ugarituko dira $[13,16]$. Axoien kasuan, hazkuntza-prozesuan sartuko dira [16, 18, 21]. Hazkuntzarekin batera migrazio-prozesua hasten da, axoi-muturraren bitartez ingurunea miatuz beren iturantz gidatuak diren bitartean [14, 17, 18, 22, 23]. Neuronek, beren funtzioa betetzen hasteko, sinapsia ezarri behar dute; hots, neuronen arteko komunikazioa, sinaptogenesia, beharrezkoa da [14, 18, 24]. Sinapsia osa dadin, neuronen axoi-muturrek dendritekin edota dendriten arantzekin kontaktu fisiko eta kimikoak ezarri behar dituzte [14]. Momentu horretatik aurrera prest daude beren funtzioa betetzen hasteko.

\subsection{EKS eta garapena}

EKSk neurotransmisoreen askatzea doitzeaz gain, nerbio-sistemaren garapenean ere funtsezko eginkizuna betetzen du. Parte-hartze hori neuronen garapenaren fase guztietan gertatzen da: proliferazioan [25], neurogenesian [26, 27], desberdintzapenean [17], axoi-hazkuntzan eta gidan [28], migrazioan [29] eta sinaptogenesian [18, 30, 31], hain zuzen ere. Garapenean zeharreko prozesu horiei buruzko ikerketa guztiak enbrioi-aroan egin dira (kasu gehienetan, in vitro ereduetan), eta EKSk garapenean jarduteko erabiltzen dituen mekanismo eta prozesuei buruz argibide asko eman dituzte. Izan ere, garapenean parte hartzen duen eKB-rik garrantzitsuena 2-AG da, eta osagai horrek $\mathrm{CB}_{1}$ hartzailearen bitartez betetzen du bere seinaleztapena. Seinaleztapen hori, berriz, neuronen transmisioan arauzkoa den atzeranzko mezulariaren izaera kanonikoa izan beharrean (sinapsi osteko konpartimentutik sinapsi aurrekora), modu autokrinoan (konpartimentu berean) gerta daitekeela ikusi da. Garapenean, beraz, EKSren jar- 
duteko moduak helduengan gertatzen direnetatik zeharo desberdinak izan daitezkeela frogatu dute.

In vitro ereduetan, garuntxoaren pikor-zeluletan eta garun-kortexeko neuronen hazkuntza zelularretan nagusiki, zelula horien aitzindariek eta zelula desberdinduek $\mathrm{CB}_{1}$ hartzailea eta DAGL- $\alpha$ entzima adierazten dituzte eta funtzionalak dira $[15,32,33,34]$. Zenbait ikerketa neurona aitzindarien proliferazio-garaian egin dira. Fase horretan, DAGL- $\alpha$ entzimak sintetizatzen duen 2-AG-ak seinaleztapen autokrinoaren bitartez eragiten duela ikusi da, $\mathrm{CB}_{1}$ hartzailearen gain bere aitzindarien populazioa zuzenean kontrolatuz $[34,35]$. Hala ere, $\mathrm{CB}_{1}$ hartzaileak neurona aitzindarien desberdintzapenean eta fenotipo helduaren gaikuntzan duen eraginaren inguruan badago nolabaiteko eztabaida. Ikerketa batzuek eKB-ak desberdintzapenean eragin negatiboa duela esaten duten arren [36, 37, 38], beste batzuek aurkako eragina duela adierazten dute [21]. Oro har, orain arte burututako ikerketetatik, $\mathrm{CB}_{1}$ hartzailearen eKB bidezko aktibazioak zelula aitzindarien proliferazioa, bizi-iraupena eta migrazioa bultzatzen dituela ondoriozta daiteke. Aldi berean, atzeratzen du aitzindarien fenotipoa proliferatzailea eta migratzaile-konpetitiboa izatetik desberdindutako fenotipo postmitotikoa izatera igarotzeko urratsa. Hala ere, tratamenduen iraupenak eta inguruneko hazkuntza-faktoreak ere modula dezakete eragin hori [17].

Horrez gain, zenbait ikerketak adierazi dute polarizazio neuronala eta neuritogenesia gertatzen diren bitartean $\mathrm{CB}_{1}$, DAGL- $\alpha$ eta MAGL axoiprozesuetan batera garraiatuak direla [26, 39, 40, 41]. Hazkuntza-prozesuan dauden axoietan, bai garuntxoaren hazkuntza zelularretan bai neurona kortikaletan, esaterako, axoiaren mutur mugikorrean $\mathrm{CB}_{1}$ eta DAGL- $\alpha$ adierazten dira. Era horretara, DAGL- $\alpha-\mathrm{k} 2-\mathrm{AG}$ sintetizatuko du $\mathrm{CB}_{1}$ hartzaileak autokrinoki aktibatuz, axoien gidaritzaren eta hazkuntzaren mesedetan [28].

MAGL degradazio-entzima axoiaren segmentu mugiezinean pilatzen da, eta beraren kontzentrazioa axoi mugikorrerantz hurbiltzerakoan murrizten da [18]. Axoiaren mutur mugikorretik at kokatzeak mutur horretan $\mathrm{CB}_{1}$ aktibatzeko 2-AG-ren kontzentrazio maila nahikoa mantentzea ahalbidetzen du, modu horretara axoien hazkuntza sustatuz. Beraz, horrek guztiak aditzera ematen du EKSk hazten ari diren neuronen morfologia polarizatua mantentzen parte-hartze garrantzitsua duela, axoi-prozesu nagusi bakarraren luzapena bultzatuz [17]. Izan ere, $\mathrm{CB}_{1}$ hartzailearen inhibizioak, neurita nagusien luzera murrizteaz gain [42], adarkadura-puntuak ugaritzen ditu [39] migrazio-prozesuaren kaltean [43].

Axoiaren mutur mugikorra bere helmugara heltzear dagoenean eta, beraz, sinapsia ezartzekotan dela, MAGL entzima axoi-prozesuaren mutur mugikorrean pilatzen hasiko da, 2-AG-ren degradazio-tasa emendatuz eta, beraz, $\mathrm{CB}_{1}$ hartzailearenganako seinaleztapena ekidinez. $\mathrm{CB}_{1}$ hartzailearen 
I. Buceta, I. Rico, J. Egaña, S. Achicallende, I. Terradillos, N. Puente, L. Reguero, N. Royo, I. Bonilla, A. Medrano, J. Mendizabal, S.M. Gómez, A. Ramos, I. Gerrikagoitia, P. Grandes, I. Elezgarai

aktibitatea murrizteak axoiaren hazkuntza mugatzen du, eta, hala, sinaptogenesia edo sinapsien sorkuntza ahalbidetu [18]. Sinaptogenesia gertatu ostean, $\mathrm{CB}_{1}$ hartzailearen maila jaitsiz joango da axoietan, eta DAGLrena handituz alde postsinaptikoan [8, 15, 26, 27, 39, 44, 45, 46, 47]. Sinapsia gaitzen denean - hau da, helduaren funtzionaltasuna lortzen duenean-, $\mathrm{CB}_{1}$ eta MAGL bukaera sinaptikoetan kokatuko dira [7, 9, 40, 48], eta DAGL- $\alpha$, bere aldetik, neuronen alde somatodendritikoan kokatuko da. Era horretara, DAGL- $\alpha-\mathrm{k}$ 2-AG sintetizatuko du alde postsinaptikoan, eta horrek era parakrinoan edo atzeranzko norabidean bukaera presinaptikoan kokatzen den $\mathrm{CB}_{1}$ aktibatuko du [8] neurotransmisoreen askatzea modulatuz.

\subsection{EKS eta garuntxoa}

EKSko osagaiek garapenean zehar nola jarduten duten arakatu den arren, ez dago ultraegitura mailako EKSko osagaien kokapena in situ edo bertatik bertara ikuskatu duen azterketarik. Izan ere, jaio aurreko garapenak metodologia-muga handiak dakartza, enbrioi-ehunaren ezaugarriak direla-eta, ultraegitura mailako azterketak egiteko. Alabaina, nerbio-sistemaren garapena ez da enbrioi-epera mugatzen, jaio osteko lehen asteetan neuronen garapen-prozesu osoak gertatzen dira burmuinaren zenbait eskualdetan. Lehen aipatu dugunez, garuntxoaren kasua dugu horietako bat. Ikerketa honetan ezaugarri horretaz baliatu gara, neuronen garapen-prozesu guztiak jaio ostean jasaten dituzten garuntxoaren kortexeko pikor-zeluletan EKSren osagaiek zer kokapen duten aztertzeko.

Garuntxoa mugimenduen doikuntzaz eta ikasketa motorraz arduratzen den nerbio-sistemako egitura bat da. Beraren garapena enbrioi-fasean hasten da, eta jaio osteko 3. astera arte ez da guztiz amaitzen karraskarietan [49]. Garuntxoaren kortexean aldaketa morfologiko garrantzitsuak gertatzen dira epe horretan zehar; horien artean, kortex horretan ugarienak diren zelulen - hots, pikor-zelulen (PZ) - , morfogenesia gauzatzen da, beste aldaketa batzuen artean [16].

\subsubsection{Garuntxoaren kortexeko pikor-zelulen jaio osteko garapena}

PZen aitzindarietatik PZak baino ez dira sortzen [13] (neurogenesia) (1. irudia). Sortu berri diren neurona horiek ugaritu egiten dira proliferazioaren bitartez (1. irudiko 1 zenbakia), eta, horrenbestez, kanpoko pikorgeruza (KPG) sortzen da [13, 16, 49].

Neuronen desberdintzapenaren lehen urratsean, neuritogenesiaren bitartez, hedadurak garatuko dituzte aurkako polo bietan (1. irudiko 2 zenbakia), eta, hala, axoi bat eta zenbait dendrita osatuko dituzte (1. irudiko 3 zenbakia). PZen kasuan, axoi-poloan ezker-eskuin bi luzakin garatuko dituzte $[13,16]$. 
Polarizazioa amaitzean, hedadurak hazkuntza-prozesuan sartuko dira [16] (1. irudiko 4 zenbakia). PZen kasuan, bi prozesu horizontalekiko elkarzuta den hirugarren prozesu bat sortzen da axoi-poloan [13, 16], «T» forma duen egitura bat sortuz. «T» horren prozesu horizontalei zuntz paraleloak (ZP) deritze [13, 16] (1. irudiko 7 zenbakia). Axoi-polotik eratorritako egitura horiek Purkinje neuronen arantza dendritikoekin (grisez) kontaktu sinaptikoak ezarriko dituzte [16, 49], eta (1. irudiko 8 zenbakia) sinapsi horiek geruza molekularra (GM) osatuko dute [16, 49]. Prozesu bertikal hori somaren migrazioari jarraituz luzatuko da $[13,16](1$. irudiko 5,6 zenbakiak), sortze-prozesuan dagoen GM zeharkatuz beheranzko bidean barneko pikor-geruzaraino (BPG) iritsi arte [13, 16, 49]. BPGra heltzeko somek garapenean dauden Purkinje neuronen geruza zeharkatu beharko dute. Purkinje neuronak garuntxoaren ardatza dira, eta berek integratzen dute garuntxora heltzen den informazio guztia.

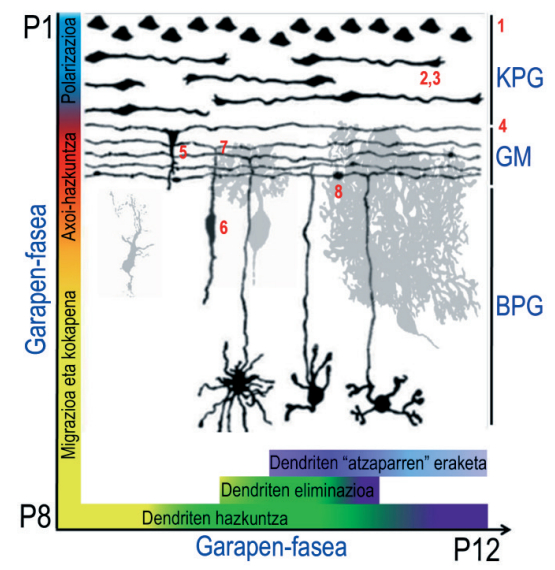

1. Proliferazioa

2. Neuritogenesia

3. Polarizazioa

4. Axoi-hazkuntza

5. Prozesu bertikalaren hedapena

6. Somaren eta prozesu bertikalaren migrazioa

7. Prozesu horizontal bien fusioa eta zuntz paraleloen sorrera

8. Sinaptogenesia

1. irudia. Arratoiaren garuntxoaren kortexeko pikor-zelulen jaio osteko morfogenesia. KPG, kanpoko pikor-geruza; GM, geruza molekularra; BPG, barneko pikor-geruza; P, jaio osteko eguna. De la Torre-Ubieta eta Azad Bonni, 2011 tik moldatuta.

Aurreko guztia kontuan hartuz, mikroskopia elektronikoko immunozitokimika-teknikez baliatu gara PZen jaio osteko garapen-faseetan zehar 2-AG-rekin erlazionatutako EKSren osagaiek $\left(\mathrm{CB}_{1}\right.$ hartzailea, eta DAGL- $\alpha$ eta MAGL entzimak) ultraegitura mailan jasan ditzaketen aldaketak aztertzeko. 
I. Buceta, I. Rico, J. Egaña, S. Achicallende, I. Terradillos, N. Puente, L. Reguero, N. Royo, I. Bonilla, A. Medrano, J. Mendizabal, S.M. Gómez, A. Ramos, I. Gerrikagoitia, P. Grandes, I. Elezgarai

\section{MATERIALAK ETA METODOAK}

\subsection{Erabilitako animaliak}

Adin desberdinetako Sprague Dawley anduiko arratoi albinoak erabili genituen: P0, P5, P12, P21 (jaiotegunekoa, 5 egunekoa, 12 egunekoa eta 21 egunekoa, hurrenez hurren) eta AH (8 asteko arratoi helduak).

Esperimentaziorako animaliak erabiltzeko eta zaintzeko protokoloa Euskal Herriko Unibertsitateko Etika eta Animalien Zainketa Batzordeak onartua izan zen (CEBA/94/2010/GRANDESMORENO). Ahalegin handia egin da erabilitako animalia kopurua murrizteko eta animalien sufrimendua saihesteko.

\subsection{Anestesia eta perfusioa}

Ultraegitura mantentzeko perfusioari ekin aurretik, animaliak anestesiatu genituen injekzio intraperitoneal baten bidez $80 / 10 \mathrm{mg} / \mathrm{kg}$ Ketamina/Xilazina sartuz. Aurretik deskribatuta zegoen bezala [50], transkardiakoki egin genituen perfusioak; lehenengo, fosfato/gatz-indargetzailea (PBS $=$ Phosphate buffered saline $)(\mathrm{pH} \mathrm{7,4)}$ pasarazten genuen 20 segundoz, eta, ondoren, finkatzaile-disoluzioa 10-15 minutuz, $4^{\circ} \mathrm{C}$-an mantenduz. Finkatzaile-disoluzioak honako konposatu hauek ditu: \% 4 formaldehido, \% 0,2 azido pikriko ase eta \% 0,1 glutaraldehido. Behin ehuna finkatuz gero, garezurretik animaliaren garuna atera, eta ehuna, garuntxoa, bibrotomoan moztu genuen $40 \mu \mathrm{m}$-ko ebakinak eginez. Garuntxoaren ebaki horiek egiteko, mikroskopia elektronikorako prozedura immunozitokimikoa baliatu genuen.

\subsection{Erabilitako antigorputzak}

Proteinak ikuskatzeko berariazko lehenengo antigorputzak eta horiek ezagutzen dituzten 2. antigorputzak erabili genituen. Gure intereseko proteinen kokapen zehatza ikuskatzeko, 2. antigorputzek 1,4 nanometroko urre partikula bat atxikia dute markatzaile moduan. Partikula hori oso txikia da, antigorputzak ehunean zehar barneratu ahal izateko. Partikularen txikitasun horrek ia ezinezkoa egiten du proteinaren kokapena mikroskopioan ikuskatzea, mikroskopio elektronikoen bereizmen-mugan aurkitzen baita. Hori dela eta, zilarrezko emultsio baten bitartez estaltzen da, eta, ondorioz, metal partikula ikusgai bat agertuko da. 
1. taula. Erabilitako lehenengo eta bigarren antigorputzen laburpena.

\begin{tabular}{cllc}
\hline Antigorputza & Etxe komertziala & Anduia & $\begin{array}{c}\text { Kontzentrazioa / } \\
\text { Diluzioa }\end{array}$ \\
\hline CB $_{1}$ & Frontier Science & Ahuntza & $2 \mu \mathrm{g} / \mathrm{ml}$ \\
\hline DAGL- $\alpha$ & Frontier Science & Untxia & $2 \mu \mathrm{g} / \mathrm{ml}$ \\
\hline MAGL & Frontier Science & Untxia & $2 \mu \mathrm{g} / \mathrm{ml}$ \\
\hline $\begin{array}{c}\text { Ahuntzaren aurkako } \\
\text { Nanogold-a }\end{array}$ & Nanoprobes & Untxia & $1: 100$ \\
\hline $\begin{array}{c}\text { Untxiaren aurkako } \\
\text { Nanogold-a }\end{array}$ & Nanoprobes & Ahuntza & $1: 100$ \\
\hline
\end{tabular}

EKSren osagaien ultraegitura mailako kokapen zehatza ezagutzeko, erabilitako antigorputzak honako hauek izan dira (1. taulan laburbiltzen dira):

Lehenengo antigorputzak:

- $\mathbf{C B}_{1}$ (Frontier Science co. Ltd.): saguaren $\mathrm{CB}_{1}$ hartzailearen C-muturreko 31 aminoazido (NM007726) ezagutzen dituen ahuntzean ekoitzitako antigorputz poliklonala.

- DAGL- $\boldsymbol{\alpha}$ (Frontier Science co. Ltd.): saguaren DAGL- $\alpha$ entzimaren C-muturreko 42 aminoazido (NM198114) ezagutzen dituen untxian ekoitzitako antigorputz poliklonala.

- MAGL (Frontier Science co. Ltd.): saguaren MAGL entzimaren 1-35 aminoazidoak (NM011844) ezagutzen dituen untxian ekoitzitako antigorputz poliklonala.

Bigarren antigorputzak:

- Ahuntzaren aurkako Nanogold-a (Nanoprobes, Inc.): untxian ekoitzitako ahuntzaren aurkako IgG-aren Fab' frakzioari dagokio. Fab' hori 1,4 nm-ko diametroko urre partikula batez markatuta dago.

- Untxiaren aurkako Nanogold-a (Nanoprobes, Inc.): ahuntzean ekoitzitako untxiaren aurkako IgG-aren Fab' frakzioari dagokio. Fab' hori 1,4 nm-ko diametrotako urre partikula batez markatuta dago. 
I. Buceta, I. Rico, J. Egaña, S. Achicallende, I. Terradillos, N. Puente, L. Reguero, N. Royo, I. Bonilla, A. Medrano, J. Mendizabal, S.M. Gómez, A. Ramos, I. Gerrikagoitia, P. Grandes, I. Elezgarai

\section{EMAITZAK}

$\mathrm{CB}_{1}$, DAGL- $\alpha$ eta MAGL proteinak identifikatu eta haien kokapen zehatza mikroskopia elektroniko mailan aztertu zen, adin desberdinetako (P0, P5, P12, P21 eta 8 asteko AH) Sprague Dawley anduiko arratoi albinoen garuntxo-xafletan (2.-7. irudiak). Garuntxo-xafla horietan baliatutako mikroskopia elektronikorako prozedura immunozitokimikari esker, $\mathrm{CB}_{1}$ hartzailea eta DAGL- $\alpha$ eta MAGL entzimak dauden leku konkretuetan urre partikulak agertuko dira.
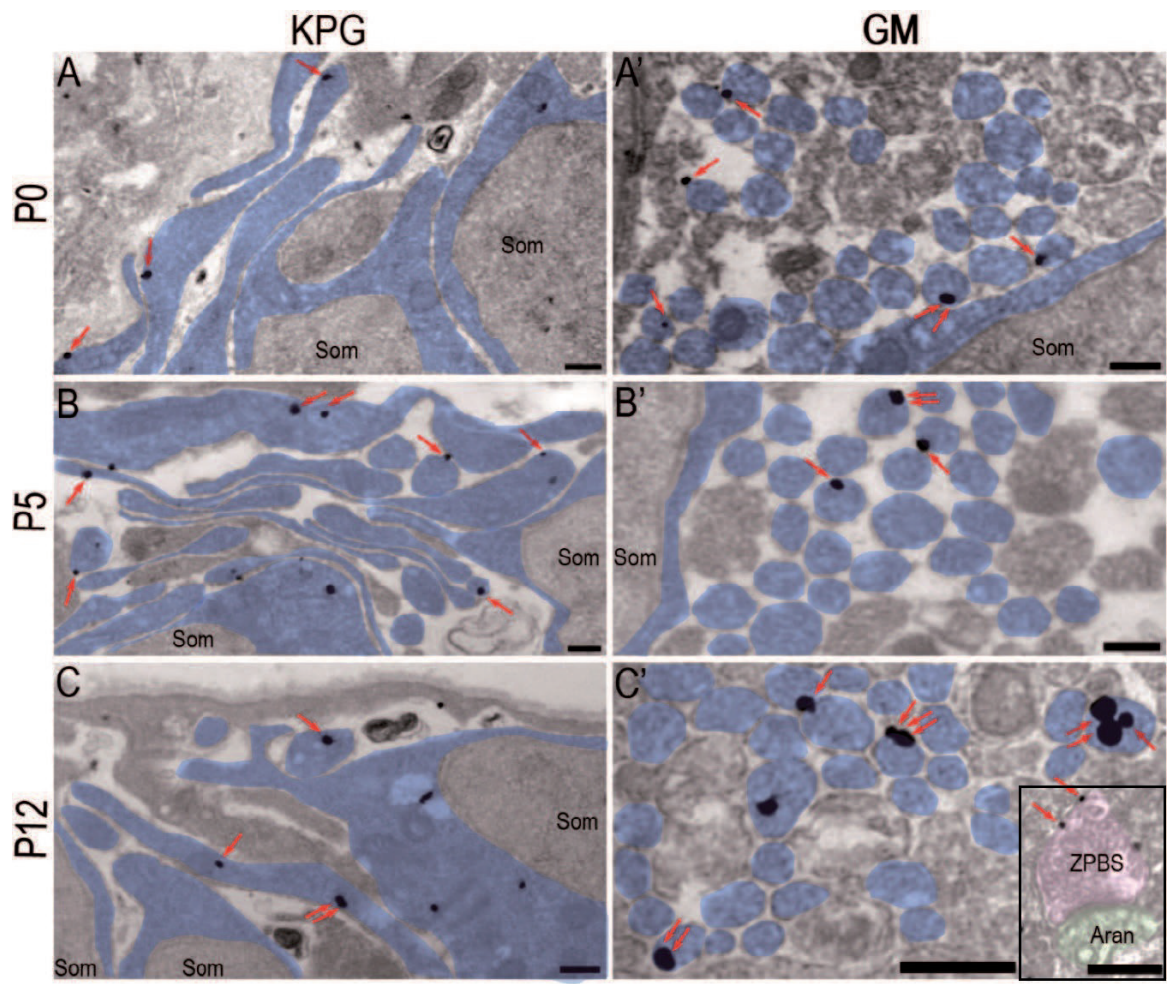

2. irudia. $\mathrm{CB}_{1}$ hartzaileak garuntxoaren kortexeko pikor-zeluletan duen ultraegitura mailako kokapena, jaio osteko honako egunetan: P0 (A, A'), P5 (B, B') eta P12 (C, C'). KPGn (A, B, C) migrazioan dauden PZen somak eta hazten ari diren axoi-prozesuak erakusten dira (urdinez). GMn (A', B', C'), ZPak adierazten dira (urdinez). Profil horietan, urre partikulak mintzean agertzen dira (gezien bidez adierazita) $\mathrm{CB}_{1}$ hartzailea identifikatuz. C' argazkiko karratuan, ZPBSren (arrosaz) eta Purkinje neuronen arantza dendritikoen (berdez) artean ezarri berritako sinapsiak erakusten dira, eta $\mathrm{CB}_{1}$ hartzailea, alde presinaptikoan, ZPBSren mintzean mantentzen da behin betiko (geziak). KPG, kanpoko pikor-geruza; GM, geruza molekularra; P, jaio osteko eguna; Som, soma; ZPBS, zuntz paraleloen bukaera sinaptikoa; Aran, arantza. Eskala-barrak: 0,25 $\mu \mathrm{m}$. 
Lortutako emaitzen arabera, aztertutako 3 proteinak KPGn eta GMn adierazten dira, eta haien kokapena eskualdearen eta adinaren arabera aldatuz doa. KPGren kasuan, $\mathrm{CB}_{1}$ hartzailea zein entzimak geruza osoan ageri dira (2., 4., 6. irudietako A, B, C irudiak). Aurreko atalean azaldu dugunez, geruza horretan proliferazioan dauden PZak azaleko aldean kokatzen dira, eta garatu ahala (proliferazioan, desberdintzapenean, axoi-hazkuntzan eta nabigazioan) beherantz bideratzen dira. $\mathrm{CB}_{1}$ hartzailea (2. irudiko $\mathrm{A}-\mathrm{C}$ ), zehazki, axoi-prozesuen mintzean adierazten da. DAGL- $\alpha$ entzima (4. irudiko A-C) prozesuen zitoplasman mintz zitoplasmatikoaren hurrentasunean kokatzen da; hau da, $\mathrm{CB}_{1}$ hartzailearen kokapenetik hurbil. MAGL entzima (6. irudiko A-C), bestalde, DAGL- $\alpha$-ren antzeko kokapena izateaz gain, mintz zitoplasmatikotik aldentzen diren zitoplasma-eskualdeetan ere adierazten da.

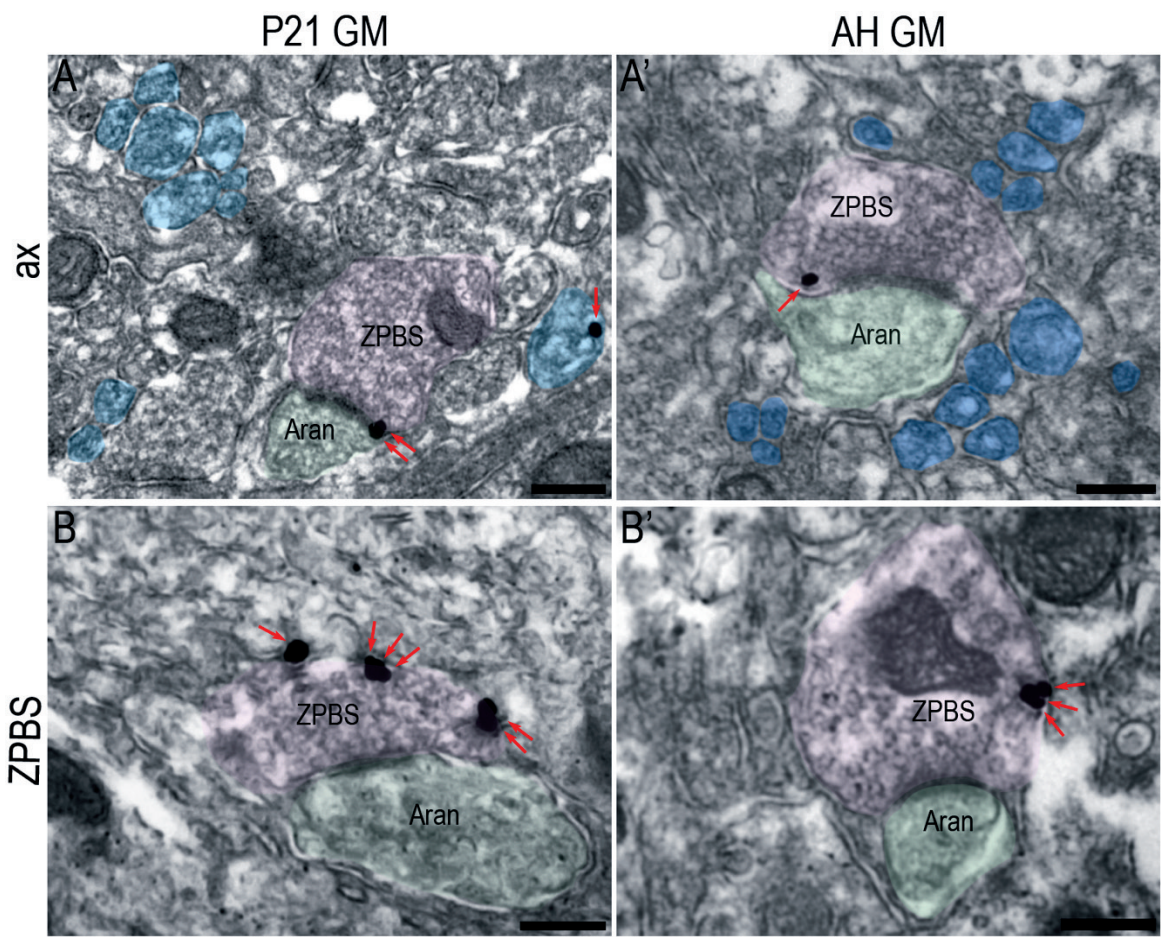

3. irudia. $\mathrm{CB}_{1}$ hartzaileak garuntxoaren kortexeko pikor-zeluletan ultraegitura mailan duen kokapena jaio osteko 21. egunean (A, B) eta animalia helduan (AH) (A', B'). A eta A' irudietan GMn ZPen axoiak erakusten dira (urdinez). Adin horietan, axoiek oso urre partikula gutxi adierazten dute (gezien bidez adierazita), eta murrizketa hori nabariagoa da $\mathrm{AHn}$. B eta B' irudietan, $\mathrm{CB}_{1}$ hartzailearen behin betiko kokapena erakusten da (gezien bidez adierazita) ZPBSren mintzean (arrosaz). GM, geruza molekularra; $\mathrm{P}$, jaio osteko eguna; $\mathrm{AH}$, animalia heldua; ax, axoiak; ZPBS, zuntz paraleloen bukaera sinaptikoa; Aran, arantza. Eskala-barrak: $0,25 \mu \mathrm{m}$. 
I. Buceta, I. Rico, J. Egaña, S. Achicallende, I. Terradillos, N. Puente, L. Reguero, N. Royo, I. Bonilla, A. Medrano, J. Mendizabal, S.M. Gómez, A. Ramos, I. Gerrikagoitia, P. Grandes, I. Elezgarai
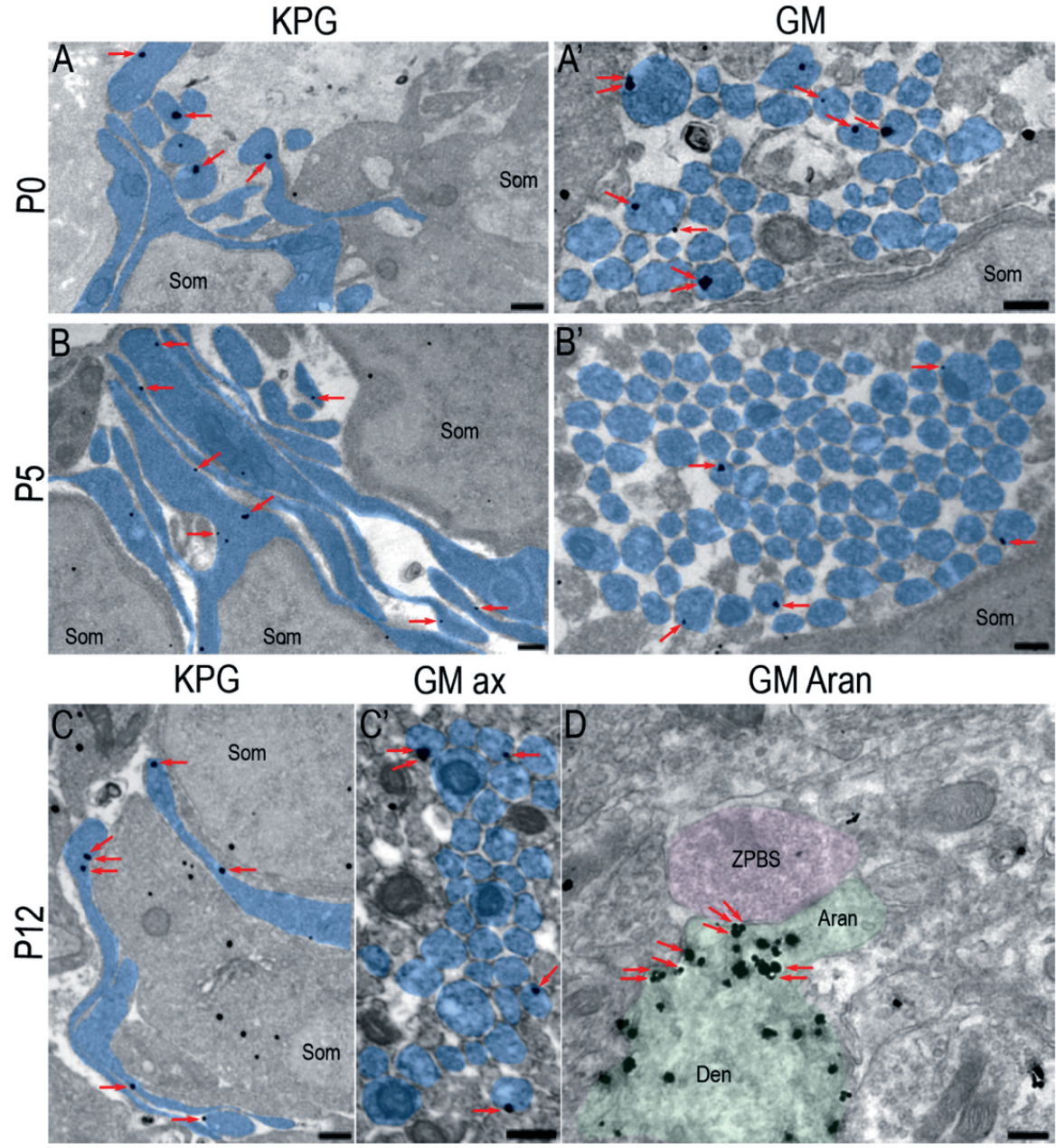

4. irudia. DAGL- $\alpha$ entzimaren ultraegitura mailako kokapen immunozitokimikoa garuntxoaren kortexeko pikor-zelulen axoi-konpartimentu desberdinetan P0 (A, A'), P5 (B, B') eta P12 (C, C', D) jaio osteko egunetan. A, B, C irudietan, KPGko bereizgarriak diren PZen axoi-prozesuak erakusten dira (urdinez) morfogenesia jasaten duten bitartean. Axoi-prozesu horiek urre partikulak adierazten dituzte mintzaren hurrentasunean, DAGL- $\alpha$ entzima identifikatuz (geziak). A', B', C' irudietan, GM erakusten da, ZPen axoiez beteta (urdinez). Profil horietan, urre partikulak mintzaren hurrentasunean agertzen dira DAGL- $\alpha$ entzima adieraziz (geziak). P12n (D irudian), DAGL- $\alpha$ elementu presinaptikotik (hots, ZPen axoietatik eta ZPBSetatik) desagertzen da, eta elementu postsinaptikoan edo Purkinje neuronen arantza eta dendriten mintzaren hurrentasunean (berdez) ageri da, bere behin betiko kokapena erakutsiz (geziak). KPG, kanpoko pikor-geruza; GM, geruza molekularra; ax, axoiak; P, jaio osteko eguna; Som, soma; ZPBS, zuntz paraleloen bukaera sinaptikoa; Aran, arantza; Den, dendrita. Eskala-barrak: 0,25 $\mu \mathrm{m}$. 


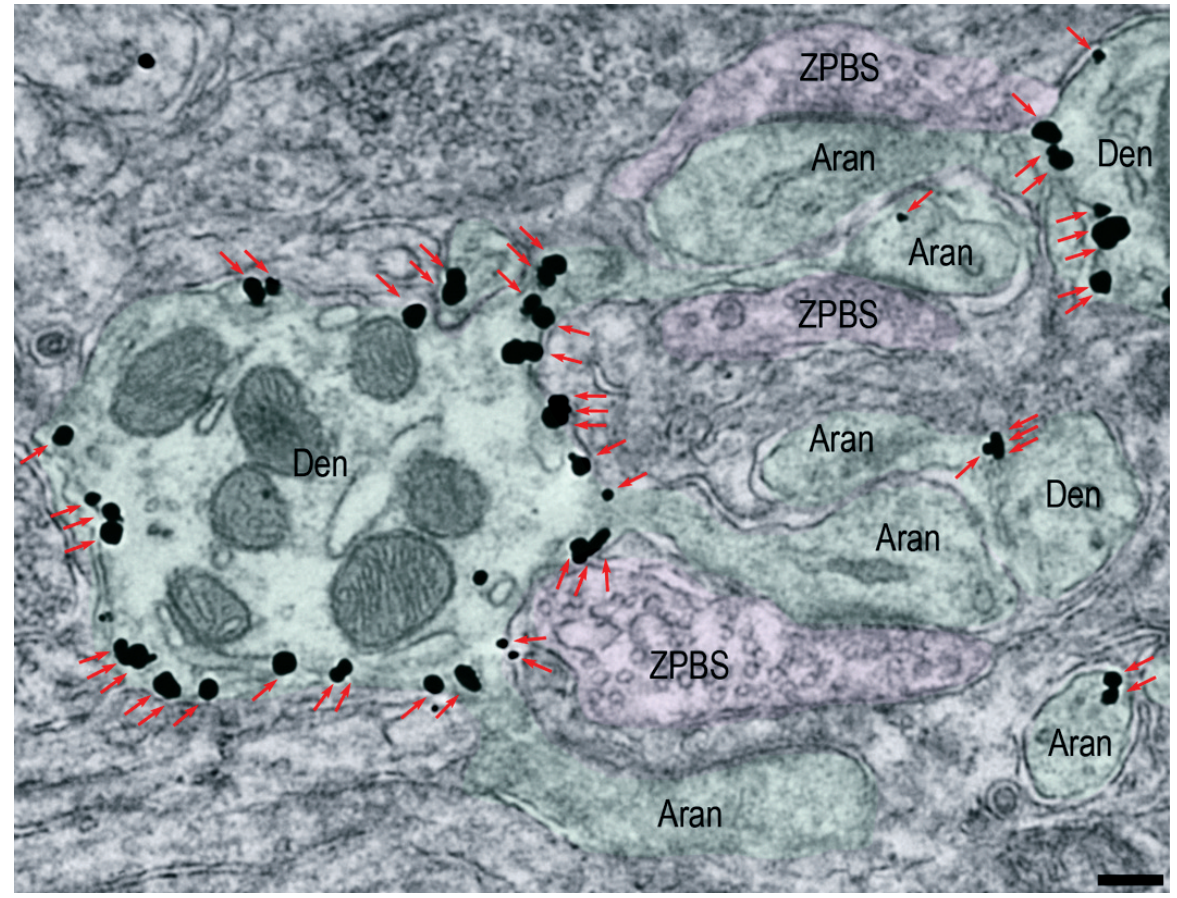

5. irudia. DAGL- $\alpha$ entzimak helduaroan (P21 eta AH) ultraegitura mailan duen kokapen immunozitokimikoa. ZPBSen (arrosaz) eta Purkinje neuronen arantza dendritikoen (berdez) arteko sinapsia erakusten da. Entzima elementu postsinaptikoan bakarrik kokatzen da (gezien bidez adierazita), hots, Purkinje neuronen dendrita eta arantza dendritikoetan, mintzaren hurrentasunean (berdez). Ikusi ZPBSen immunomarkaketaren gabezia. ZPBS, zuntz paraleloen bukaera sinaptikoa; Aran, arantza; Den, dendrita. Eskala-barrak: 0,25 $\mu \mathrm{m}$.

GM (2. eta 6. irudietako A', B', C' irudiak eta 4 .irudiko A', B', C', D), PZek osatu berri dituzten ZPen kokalekua da. Izan ere, GM garatuz doan heinean, KPG desagertuz doa. PZen axoi-prozesu horizontal zein bertikal horiek hazte- eta migratze-prozesuetan aurkitzen dira. Fase horretan dauden axoiek ere aztertutako hartzaile eta entzimek KPGn duten kokapen berbera dute: $\mathrm{CB}_{1}$ hartzailea axoien mintzean adierazten da (2. irudiko $A^{\prime}-C^{\prime}$ ); DAGL- $\alpha$, mintz zitoplasmatikoaren hurrentasunean (4. irudiko A'-C'), eta MAGL, bere aldetik, mintzaren hurrentasunean, baita mintzetik aldenduago dauden zitoplasmako eskualdeetan ere (6. irudiko A'-C'). Hala ere, P12ren GM honetan, bi motatako ZPak aurkitzen dira, hala nola heltze-prozesuan daudenak, batetik, eta helduagoak direnak eta sinapsia ezartzen hasiko direnak, bestetik (2. irudiko C' irudiko laukian, 4. irudiko D irudian, eta 6. irudiko C' karratuan). Azken horiek orain arte agertzen 
I. Buceta, I. Rico, J. Egaña, S. Achicallende, I. Terradillos, N. Puente, L. Reguero, N. Royo, I. Bonilla, A. Medrano, J. Mendizabal, S.M. Gómez, A. Ramos, I. Gerrikagoitia, P. Grandes, I. Elezgarai

ez zen profil berri bat osatuko dute, ZPen bukaera sinaptikoei (ZPBS) dagokiena. Bukaera sinaptiko horiek Purkinje neuronen arantza dendritikoekin sinapsi kitzikatzaileak ezartzen dituzte GMn zehar (2. irudiko C' laukian, 4. irudiko D laukian eta 6. irudiko C' laukian). P12n orduan, heldu gabe dauden prozesuek orain arte KPG eta GM garatze-prozesuan dauden zuntzetako kokapen bera azaltzen duten bitartean, garatuta dauden ZPetan $\mathrm{CB}_{1}$ hartzailea ZPBSren mintzean adierazten hasten da (2. irudiko C' irudiko laukian), hartzaile horrek helduan izango duen behin betiko kokapena erakutsiz (3. irudiko B eta B'), eta axoi-zuntzean, berriz, desagertuz doa (3. irudiko A eta A' laukiak). P12n entzimen kokapenean ere gertatzen dira aldaketak: DAGL- $\alpha$ entzima gutxituz doazen ZP heldugabeetan aurkituko da soilik (4. irudiko A', B' eta C' laukietan); izan ere, gero eta gehiago diren ZP helduetan ez da adieraziko, ezta ZPBSn ere (4. irudiko D laukian). Aro honetako aldaketarik deigarriena zera da: DAGL- $\alpha$ profil postsinaptikoan adierazten hasten dela; hots, Purkinje neuronen arantza dendritikoan (4. irudiko D laukian). Horrela, entzima horrek, hartzailearekin gertatzen zen bezala, P12rako bere behin betiko kokapena erakusten du (5. irudia). MAGL entzima identifikatzen duten urre partikulak garatu gabeko ZPetan adierazten dira, haien mintzaren hurrentasunean eta zitoplasman (6. irudiko A'-C' laukiak) KPGko prozesuen antzera baina ZPBSetan; hau da, sinapsia gaitzen denean, mintzaren inguruetatik aldendu eta bukaera sinaptikoen zitoplasman kokatzen da (6. irudiko C' laukian). Kokapen hori helduan ere ohikoena da (7. irudiko A eta B laukiak). 

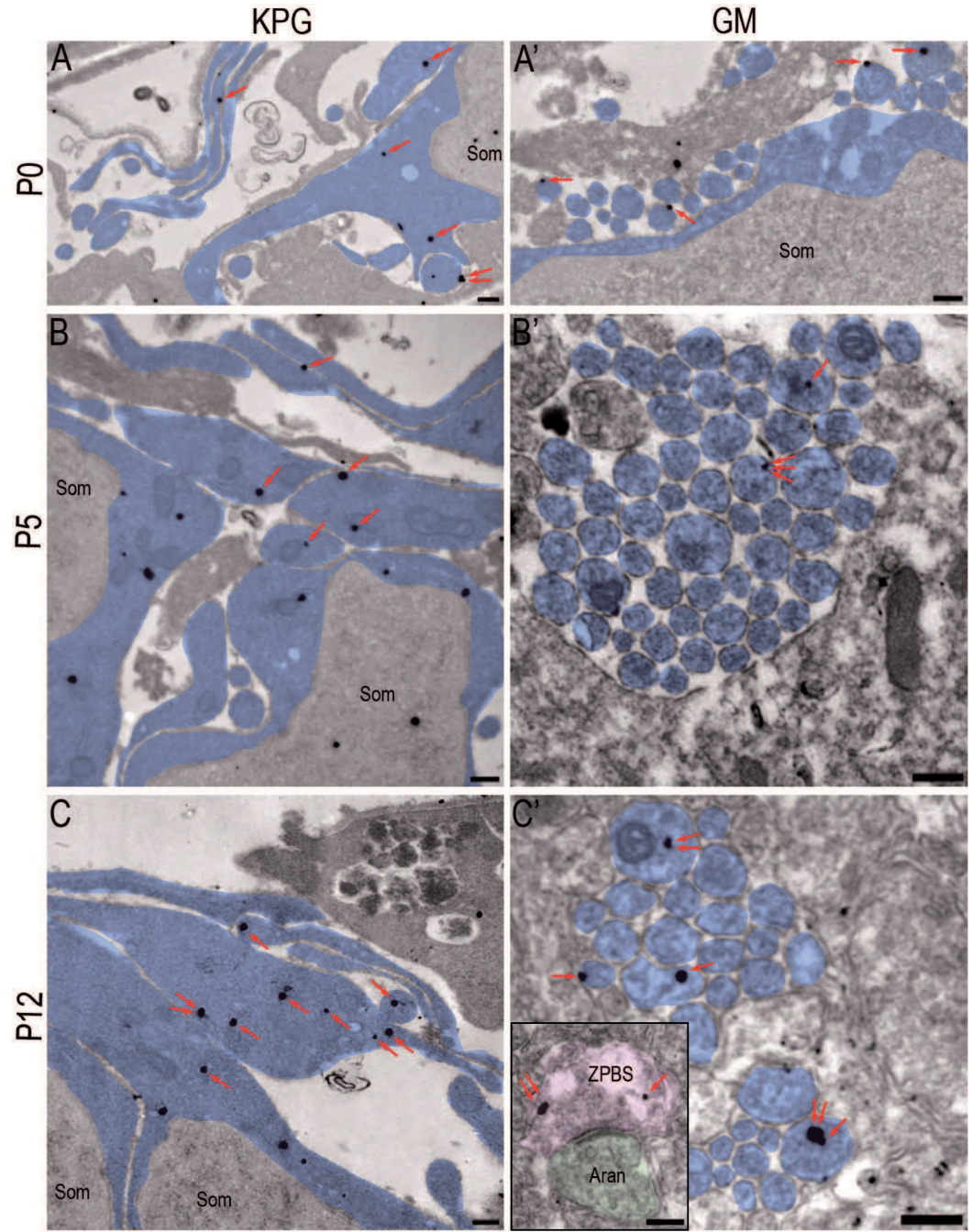

6. irudia. MAGL entzimak garuntxoaren kortexeko pikor-zeluletan duen ultraegitura mailako kokapena, jaio osteko honako egunetan: P0 (A, A'), P5 (B, B') eta P12 (C, C'). A, B, C irudiek KPGn PZen axoi-prozesuak hazte- eta nabigatze-prozesuan erakusten dituzte (urdinez). Axoi-prozesu horiek urre partikulak dituzte MAGL identifikatuz, bai mintzaren hurrentasunean bai eta zitoplasman ere (geziak). A', B', C' irudietan GM adierazten da, zeinetan MAGL identifikatzen dituzten immunopartikulak (gezien bidez adierazita) ZPen axoien (urdinez) mintzaren hurrentasunean eta zitoplasman ere kokatzen diren. C' irudiko karratuan, P12n, MAGL ZPBSen (arrosaz) mintzaren hurrentasunean eta zitoplasman ere adierazten da bere behin betiko kokapena erakutsiz; hots, alde presinaptikoan mantentzen da. KPG, kanpoko pikor geruza; GM, geruza molekularra; P, jaio osteko eguna; Som, soma; ZPBS, zuntz paraleloen bukaera sinaptikoa; Aran, arantza. Eskala-barrak: 0,25 $\mu \mathrm{m}$. 
I. Buceta, I. Rico, J. Egaña, S. Achicallende, I. Terradillos, N. Puente, L. Reguero, N. Royo, I. Bonilla, A. Medrano, J. Mendizabal, S.M. Gómez, A. Ramos, I. Gerrikagoitia, P. Grandes, I. Elezgarai

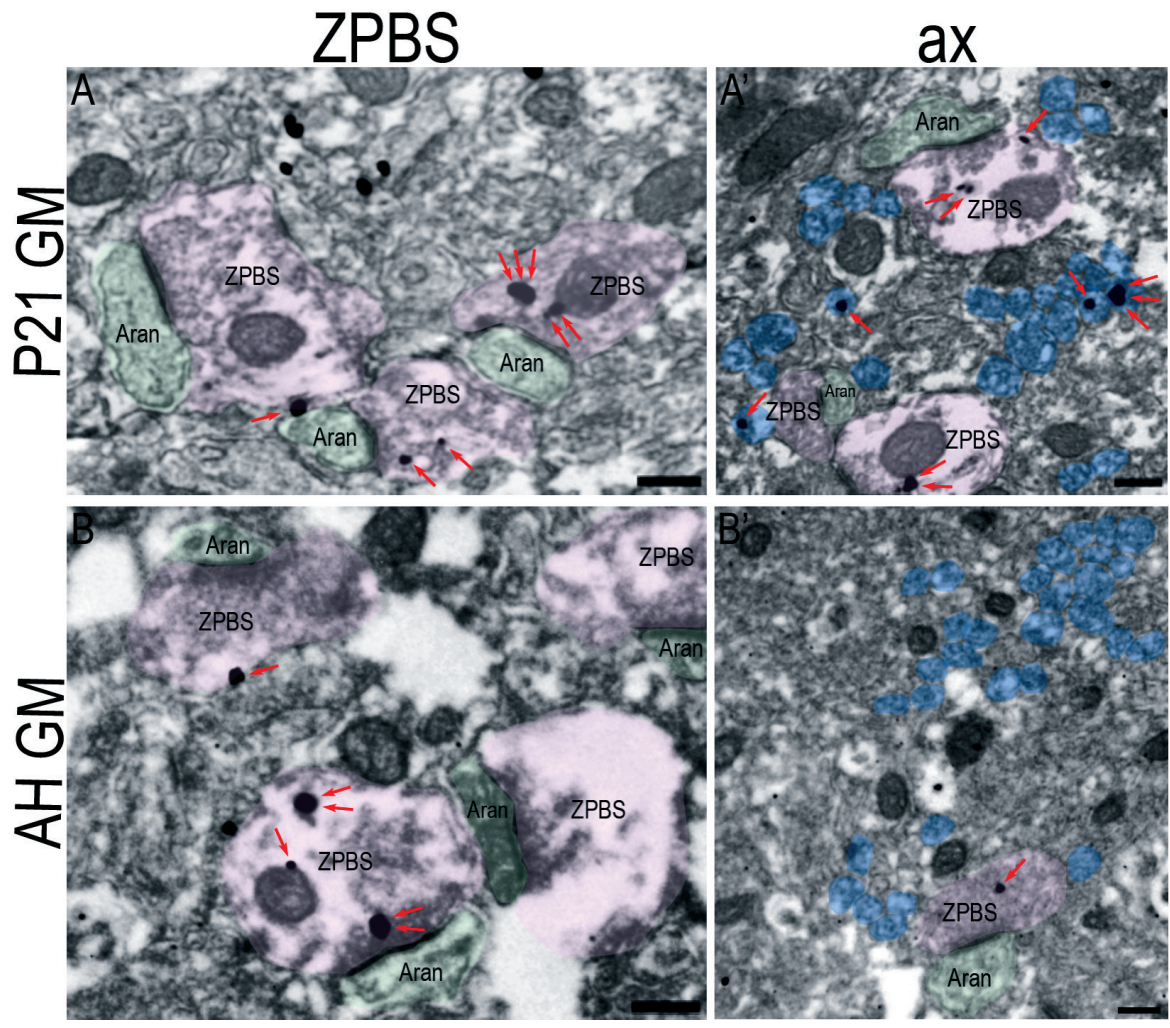

7. irudia. MAGL entzimak zuntz paraleloetan duen ultraegitura mailako kokapena jaio osteko 21. egunean (P21) (A, A') eta AHn (B, B'). A' eta B' irudietan zuntz paraleloen axoiak erakusten dira (urdinez). Axoi horiek MAGL entzima identifikatzen duten urre partikula gutxi adierazten dituzte (gezi bidez adierazita). A irudian, entzima identifikatzen duten urre partikulak ZPBSen mintzean eta zitoplasman ere adierazten dira; $\mathrm{B}$ irudian, entzimak behin betiko kokapena erakusten du, nagusiki ZPBSen zitoplasman (gezi bidez adierazita) (ikusi orobat B' irudian). GM, geruza molekularra; $\mathrm{P}$, jaio osteko eguna; $\mathrm{AH}$, animalia heldua; ax, axoiak; ZPBS, zuntz paraleloen bukaera sinaptikoa; Aran, arantza. Eskala-barrak: $0,25 \mu \mathrm{m}$.

\section{EZTABAIDA}

Gure emaitzek erakutsi dute EKSko $\mathrm{CB}_{1}$ hartzaileak eta 2-AG-aren sintesi- eta degradazio-entzimek aldaketa topografiko esanguratsuak jasaten dituztela PZen jaio osteko garapenean zehar. Aldaketa horiek sistemaren eskakizun funtzionalarekin batera doaz: garapen neuronala hasieran $[8,14$, $17,30,39,40,41,42,51,52,53,54,55]$, eta, sistema helduz doan heinean, 
neurotransmisioaren modulazioa $[8,14,17,56,57,58,59,60]$ (glutamato neurotransmisorearena kasu honetan).

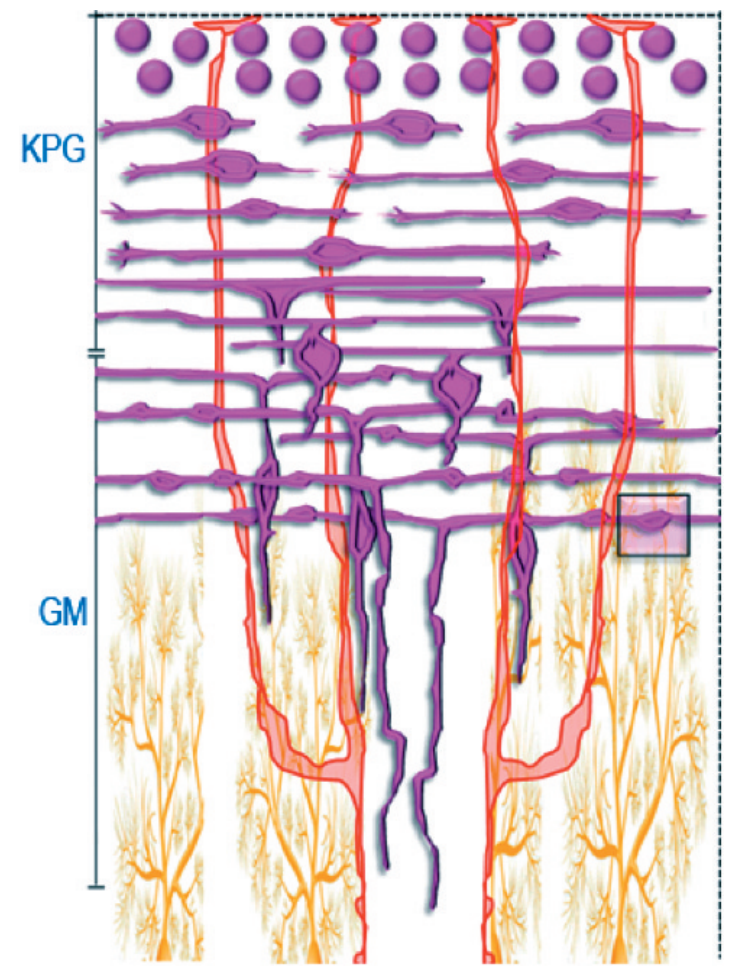

8. irudia. Jaio ostean gertatzen den garuntxoko kortexeko pikor-zelulen (arrosaz) morfogenesia erakusten duen eskema. Jaio osteko 0 , 5 . eta 12. egunetan (P0, P5, P12) PZek jasaten dituzten garapen-prozesu guztiak batera irudikatu dira. Goitik behera: proliferazioa, polarizazioa, axoiprozesuen hazkuntza, migrazioa, zuntz paraleloen sorrera, sinapsien ezarpena. Gorriz: Bergmann glia; horiz: Purkinje neuronak. KPG, kanpoko pikor-geruza; GM, geruza molekularra.

Ikerketa-lan honetan lortutako emaitzek orain arte egindako ikerketei in situ egindako ultraegitura mailako lehen substratu morfologikoa ematen diote (8. eta 9. irudiak). Orain arte gaiaren inguruan egin diren ikerketetatik eratorritako informazioa bateratuz, esan dezakegu EKSko osagai talde bat (2-AG eKB-arekin erlazionatuta dauden hartzaile eta entzimak, hain zuzen ere) desberdin aritzen direla bai funtzio bai kokapen aldetik garape- 
I. Buceta, I. Rico, J. Egaña, S. Achicallende, I. Terradillos, N. Puente, L. Reguero, N. Royo, I. Bonilla, A. Medrano, J. Mendizabal, S.M. Gómez, A. Ramos, I. Gerrikagoitia, P. Grandes, I. Elezgarai

nean helduaroarekin konparatuz $[8,14,15,17,18,26,30,31,40,42,61$, 62]. Garapenean zehar DAGL- $\alpha$ hazkuntza-konoan (hots, axoiaren mutur mugikorrean eta baita axoi-prozesuetan ere) mintzetik hurbil kokatzen da; 2-AG eKB-a sintetizatuz, axoi berean kokatzen den $\mathrm{CB}_{1}$ modu autokrinoan aktibatuz, axoiaren hazkuntza eta gida bultzatzen du [8, 17, 18, 21, 28, 40, 41, 42, 63]. MAGL konpartimentu berean [26, 39, 40, 41] mintzaren hurbiltasunean eta zitoplasman oro har adierazten da [9, 64, 65, 66]; bertan, 2-AG eKB-a degradatuz haren maila erregulatuko du [40]. Horrela, bi entzima horien arteko orekak, sintesi-degradazio orekak, 2-AG eKB-aren kontzentrazioa moldatuz erregulatuko du hazkuntzaren abiadura [40]. Hazkuntza hori axoia bere itu postsinaptikora hurbiltzen den heinean jaitsiz doa [40]. P12n, seinaleztapen autokrinoa mantentzen da, eta osagai guztiek axoian jarraitzen dute, axoi-hazkuntzak aurrera jarraitzen duen bitartean. Aldi berean, garapen-prozesuan dauden beste neurona batzuk (garuntxoaren kasuan, Purkinje neuronak) DAGL- $\alpha$ adierazten hasten dira [8, 42, 62], eta, beraz, 2-AG sintetizatzen; orduan, halako batean, 2-AG-ren seinaleztapena bi bidetatik bideratuko da; 2 . kasu horretan, kontzentrazioa askoz handiagoa da, eta ZPei adierazten die beren itu diren Purkinje neuronetara hurbiltzen ari direla. ZPetan kokatzen diren $\mathrm{CB}_{1}$ hartzaileak iturri berri oparo horretako 2-AG-ak aktibatzen duenean ZPetako DAGL- $\alpha$-ren adierazpena desagertuz joango da $[8,26,39,40,42,46,52]$. Une horretan hasten da helduan gertatzen den seinaleztapen parakrinoa edo atzeranzko norabideko seinaleztapena [8, 40]. MAGLren kasuan, ZPBSn dagoen 2-AG-a degradatzen du $[40,66]$, hazkuntza mugatuz eta sinaptogenesia ezartzeko aukera emanez [40]. Beraz, P12n EKSren seinaleztapen autokrinoaren gainbehera eta parakrinoaren ezarpenaren hasiera gertatuko da. Era horretara, heldu berri diren ZPen axoiek Purkinje neuronekin geruza molekularrean sinapsiak ezartzen dituzte, eta funtzional izaten hasten dira. P12n sinapsiak ezarrita daudenean, aztertutako hartzaile eta entzimen behin betiko kokapena mantendu egiten da adinarekin. P21en eta AHn lortutako emaitzetan, berriz, nahiz eta aldaketa esanguratsurik ez hauteman, badago aldea haien artean; izan ere, sinapsi garatu kopurua emendatuz doa.

Ikerketa honen bitartez, lehen aldiz ikusi da sistema biologiko oso batean garuntxoaren jaio osteko garapenean EKSn zehar gertatzen diren aldaketak garapen prozesuen faseekin guztiz lotuak daudela. Izan ere, garapenean gertatzen diren aldaketekin bat datoz kannabinoide-osagaien ultraegitura mailako kokapen-aldaketak. Horrek iradokitzen du EKS, behintzat 2-AG-rekin erlazionatzen diren osagaiei dagokienez, neuronek osatzen dituzten sistemen garapenaren parte-hartzaile garrantzitsua dela. 


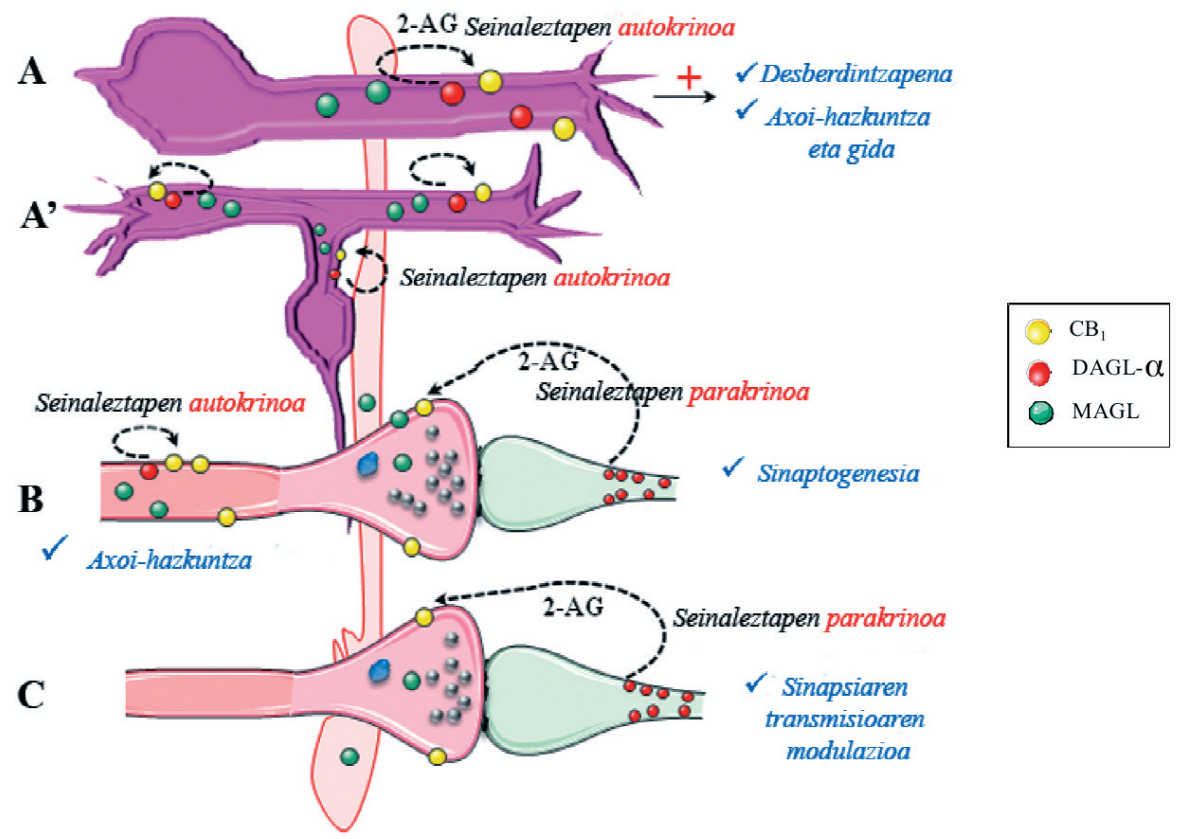

9. irudia. $\quad \mathrm{CB}_{1}$ hartzaileak eta DAGL- $\alpha$ eta MAGL entzimek pikor-zelulen axoiprozesuetan eta axoi heldu edo zuntz paraleloetan duten ultraegitura mailako kokapenaren eskema. Eskema honetan orain arte lortutako emaitzak laburbiltzen dira. A-C: osagai desberdinen kokapena PZen garapen-faseetan zehar. A eta A' eskemetan, desberdintzapen-fasean dagoen PZ bat erakusten da. A eskeman, axoi-prozesu heldugabe monopolar bat irudikatzen da, eta A' eskeman, axoi-prozesu heldugabe bipolar bat nabigatzen eta hazte-prozesuan beheranzko prozesu premigratzailearekin batera. $\mathrm{B}$ eta $\mathrm{C}$ eskemetan, 8. irudiko eskeman adierazitako geruza molekularrean laukian dagoen profilaren handipena da. B eskeman, P12n, axoi-hazkuntzak dirauen bitartean gertatzen hasten den sinaptogenesia erakusten da; hots, ZPak (arrosaz) Purkinje neuronen arantza dendritikoekin (berdez) ezarritako sinapsia. C eskema P21i eta animalia helduari dagokie. KPG, kanpoko pikor-geruza; GM, geruza molekularra; 2-AG, 2-arakidonilglizerola.

\section{ETORKIZUNEKO NORABIDEA}

Ikerketa honetan EKSk garuntxoaren jaio osteko garapenean parte hartzen duela erakutsi da. Gureaz gain, beste ikerlan batzuek ere $\mathrm{CB}_{1}$ hartzaileak garapen-prozesuetan duen garrantzia frogatu dute. Hori horrela izanik, interesgarria litzateke etorkizunean hartzaile hau farmakologikoki inhibitzeak edo eKB-en tonua aldatzeak axoi hauen heltze-prozesuan izan dezakeen eragina aztertzea. 
I. Buceta, I. Rico, J. Egaña, S. Achicallende, I. Terradillos, N. Puente, L. Reguero, N. Royo, I. Bonilla, A. Medrano, J. Mendizabal, S.M. Gómez, A. Ramos, I. Gerrikagoitia, P. Grandes, I. Elezgarai

Aurreko egoerak sakonean ezagutu ondoren, haurdun dauden emakumeen kalamu-kontsumoak umekietan izan ditzakeen eraginak aztertze aldera, umedun dauden saguetan $\Delta^{9}$-THC-a exogenoki administratzeak kumeen neuronen garapenean izan ditzakeen eraginak fenotipikoki aztertzea interesgarria izango litzateke, moldaketa morfologikorik jasaten duten ala ez argitzeko [67, 68].

Azkenaldian, bestalde, jaio osteko garapenean EKSren osagaien maila aldatzea oinarri duten tratamenduekin saiakerak egiten hasi dira, batez ere hipoxia perinatala gertatzen den kasuetan, baita epilepsia errefraktarioan ere. Tratamendu horiek batez ere kannabinoide ez-psikotropiko den kannabidiolan (CBD) oinarritzen dira [69, 70, 71, 72], eta, kannabinoide horren eragina $\mathrm{CB}_{1}$ hartzailearen bitartez bideratzen ez dela badirudi ere, eKB-etan oinarritutako tratamendu horiek neuronen arteko komunikazio-ezarpenean ultraegitura mailan moldaketak eragiten dituzten aztertzeak berebiziko garrantzia izan dezake tratamendu horien albo-ondorio posibleak saihesteko.

\section{ESKER ONAK}

Ikerketa honek honako diru-laguntza hauek izan ditu: Euskal Herriko Unibertsitateko (UPV/EHU) beka (PIF09/2009/PIF09228); Eusko Jaurlaritza (BCG IT764-13); Euskal Herriko Unibertsitatea (UPV/EHU UFI11/41); MINECO/FEDER, UE (SAF2015-65034-R); Droga-menpekotasun Arazoen Sarea (RTA) - Carlos III. Osasun Institutua (ISC-III); Europar Batasuneko Eskualde Garapenerako Funtsa (ERDF-EU) (RD16/0017/0012).

\section{BIBLIOGRAFIA}

[1] OKAMOTO Y., MORISHITA J., TSUBOI K., TONAI T., UEDA N. 2004. «Molecular characterization of a phospholipase D generating anandamide and its congeners». J Biol Chem, 279, 5298-5305.

[2] OKAMOTO Y., WANG J., MORISHITA J., UEDA N. 2007. «Biosynthetic pathways of the endocannabinoid anandamide». Chem Biodivers, 4, 1842-1857.

[3] WANG J., OKAMOTO Y., MORISHITA J., TSUBOI K., MIYATAKE A., UEDA N. 2006b. «Functional analysis of the purified anandamide-generating phospholipase $\mathrm{D}$ as a member of the metallo-beta-lactamase family». $J$ Biol Chem, 281, 12325-12335.

[4] JIN X.H., OKAMOTO Y., MORISHITA J., TSUBOI K., TONAI T., UEDA N. 2007. «Discovery and characterization of a Ca2 + -independent phosphatidylethanolamine $\mathrm{N}$-acyltransferase generating the anandamide precursor and its congeners». J Biol Chem, 282, 3614-3623. 
[5] UEDA N., KURAHASHI Y., YAMAMOTO S., TOKUNAGA T. 1995. «Partial purification and characterization of the porcine brain enzyme hydrolyzing and synthesizing anandamide». J Biol Chem, 270, 23823-23827.

[6] BASAVARAJAPPA B.S. 2007. «Critical enzymes involved in endocannabinoid metabolism». Protein Pept Lett, 14, 237-246.

[7] KANO, M., OHNO-SHOSAKU, T., HASHIMOTODANI, Y., UCHIGASHIMA, M., WATANABE, M. 2009. «Endocannabinoid-mediated control of synaptic transmission». Physiol Rev, 89, 309-380.

[8] BISOGNO, T., HOWELl, F., WILliAMS, G., MINASSI, A., CASCIO, M.G., LIGRESTI, A., MATIAS, I., SCHIANO-MORIELLO, A., PAUL, P., WILLIAMS, E.J., GANGADHARAN, U., HOBBS, C., DI MARZO, V., DOHERTY, P. 2003. «Cloning of the first sn1-DAG lipases points to the spatial and temporal regulation of endocannabinoid signaling in the brain». $J$ Cell Biol, 163, 463-468.

[9] DINH, T.P., FREUND, T.F., PIOMELLI, D. 2002. «A role for monoglyceride lipase in 2-arachidonoylglycerol inactivation». Chem Phys Lipids, 121, 149-158.

[10] DINH T.P., KATHURIA S., PIOMELLI D. 2004. «RNA interference suggests a primary role for monoacylglycerol lipase in the degradation of the endocannabinoid 2-arachidonoylglycerol». Mol Pharmacol, 66, 1260-1264.

[11] VANDEVOORDE S., LAMBERT D.M. 2007. «The multiple pathways of endocannabinoid metabolism: a zoom out». Chem Biodivers, 4, 1858-1881.

[12] DE PETROCELLIS, L., CASCIO, M.G., DI MARZO, V. 2004. «The endocannabinoid system: a general view and latest additions». Br J Pharmacol, 141, 765-774.

[13] SOTELO, C. 2004. «Cellular and genetic regulation of the development of the cerebellar system». Progress in Neurobiology, 72, 295-339.

[14] HARKANY, T., GUZMÁN, M., GALVE-ROPERH, I., BERGHUIS, P., DEVI, L. A., MACKIE, K. 2007. «The emerging functions of endocannabinoid signaling during CNS development». Trends in Pharmacological Sciences, 28, 83-92.

[15] GAlVE-ROPERH I., PALAZUELOS J., AGUADO T., GUZMÁN M. 2009. «The endocannabinoid system and the regulation of neural development: potential implications in psychiatric disorders». Eur Arch Psychiatry Clin Neurosci, 259, 371-382.

[16] DE LA TORRE-UBIETA, L., BONNI, A. 2011. «Transcriptional regulation of neuronal polarity and morphogenesis in the mammalian brain». Neuron, 72, 22-40.

[17] GAFFURI, A.L., LADARRE, D., LENKEI, Z. 2012. «Type-1 cannabinoid receptor signaling in neuronal development». Pharmacology, 90, 19-39.

[18] KEIMPEMA, E., MACKIE, K., HARKANY, T. 2011. «Molecular model of cannabis sensitivity in developing neuronal circuits». Trends Pharmacol Sci, 32, 551-561.

[19] KAWAJI, K., UMESHIMA, H., EIRAKU, M., HIRANO, T., KENGAKU, M. 2004. «Dual phases of migration of cerebellar granule cells guided by axonal and dendritic leading processes». Mol Cell Neurosci, 25, 228-240.

[20] LUO, L. 2000. «RHO GTPASES in neuronal morphogenesis». Nature Reviews Neuroscience, 1, 173-180. 
I. Buceta, I. Rico, J. Egaña, S. Achicallende, I. Terradillos, N. Puente, L. Reguero, N. Royo, I. Bonilla, A. Medrano, J. Mendizabal, S.M. Gómez, A. Ramos, I. Gerrikagoitia, P. Grandes, I. Elezgarai

[21] SOLTYS, J., YUSHAK, M., MAO-DRAAYER, Y. 2010. «Regulation of neural progenitor cell fate by anandamide». Biochem Biophys Res Commun, 400, 21-26.

[22] TESSIER-LAVIGNE, A. M., GOODMAN, C. S., TESSIER-LAVIGNE, M. 2012. «The Molecular Biology of Axon Guidance». Science, 274, 1123-1133.

[23] MUELLER, B. K. 1999. «Growth cone guidabnce: First Steps Towards a Deeper Understanding». Annual Review Of Neuroscience, 22, 351-388.

[24] SANES, J. R., LICHTMAN, J. W. 1999. «Development of the Vertebrate Neuromuscular Junction». Annual Review of Neuroscience, 22, 389-442.

[25] AGUADO, T., PALAZUELOS, J., MONORY, K., STELLA, N., CRAVATT, B., LUTZ, B., MARSICANO, G., KOKAIA, Z., GUZMÁN, M., GALVEROPERH, I. 2006. «The endocannabinoid system promotes astroglial differentiation by acting on neural progenitor cells». J Neurosci, 26,1551-1561 .

[26] BERGHUIS, P., RAJNICEK, A.M., MOROZOV, Y.M., ROSS, R.A., MULDER, J., URBÁN, G.M., MONORY, K., MARSICANO, G., MATTEOLI, M., CANTY, A., IRVING, A.J., KATONA, I., YANAGAWA, Y., RAKIC, P., LUTZ, B., MACKIE, K., HARKANY, T. 2007. «Hardwiring the brain: endocannabinoids shape neuronal connectivity». Science, 316, 1212-1216.

[27] DE SALAS-QUIROGA, A., DÍAZ-ALONSO, J., GARCÍA-RINCÓN, D., REMMERS, F., VEGA, D., GÓMEZ-CAÑAS, M., LUTZ, B., GUZMÁN, M., GALVE-ROPERH, I. 2015. «Prenatal exposure to cannabinoids evokes long-lasting functional alterations by targeting CB1 receptors on developing cortical neurons». Proc Natl Acad Sci U S A, 112, 13693-13698.

[28] WILLIAMS, E.J., WALSH, F.S., DOHERTY, P. 2003. «The FGF receptor uses the endocannabinoid signaling system to couple to an axonal growth response». J Cell Biol, 160, 481-486.

[29] ZHOU, Y., OUDIN, M.J., GAJENDRA, S., SONEGO, M., FALENTA, K., WILLIAMS, G., LALLI, G., DOHERTY, P. 2015. «Regional effects of endocannabinoid, BDNF and FGF receptor signalling on neuroblast motility and guidance along the rostral migratory stream». Mol Cell Neurosci, 64, 32-43.

[30] FERNÁNDEZ-RUIZ, J., BERRENDERO, F., HERNÁNDEZ, M.L., RAMOS, J.A. 2000. «The endogenous cannabinoid system and brain development». Trends Neurosci, 23, 14-20.

[31] BERGHUIS, P., DOBSZAY, M.B., WANG, X., SPANO, S., LEDDA, F., SOUSA, K.M., SCHULTE, G., ERNFORS, P., MACKIE, K., PARATCHA, G., HURD, Y.L., HARKANY, T. 2005. «Endocannabinoids regulate interneuron migration and morphogenesis by transactivating the TrkB receptor». Proc Natl Acad Sci U S A, 102, 19115-19120.

[32] HARKANY, T., KEIMPEMA, E., BARABÁS, K., MULDER, J. 2008a. «Endocannabinoid functions controlling neuronal specification during brain development». Mol Cell Endocrinol, 286, S84-S90.

[33] NOGUERON, M.I., PORGILSSON, B., SCHNEIDER, W.E., STUCKY, C.L., HILLARD, C.J. 2001. «Cannabinoid receptor agonists inhibit depolarization-induced calcium influx in cerebellar granule neurons». J Neurochem, 79, 371-381. 
[34] TRAZZI, S., STEGER, M., MITRUGNO, V.M., BARTESAGHI, R., CIANI, E. 2010. «CB1 cannabinoid receptors increase neuronal precursor proliferation through AKT/glycogen synthase kinase-3beta/beta-catenin signaling». J Biol Chem, 285, 10098-10109.

[35] MACCARRONE, M., GUZMÁN, M., MACKIE, K., DOHERTY, P., HARKANY, T. 2014. «Programming of neural cells by (endo) cannabinoids: from physiological rules to emerging therapies». Nature Reviews Neuroscience, 15, 786-801.

[36] RUEDA D., NAVARRO B., MARTINEZ-SERRANO A., GUZMAN M., GALVE-ROPERH I. 2002. "The endocannabinoid anandamide inhibits neuronal progenitor cell differentiation through attenuation of the Rap1/B-Raf/ ERK pathway». J Biol Chem, 277, 46645-46650.

[37] JIANG W., ZHANG Y., XIAO L., VAN CLEEMPUT J., JI S.P., BAI G., ZHANG X. 2005. «Cannabinoids promote embryonic and adult hippocampus neurogenesis and produce anxiolytic- and antidepressant-like effects». $J$ Clin Invest, 115, 3104-3116.

[38] SIDERIS A., BEKKER T., CHAN W.S., MONTOYA-GACHARNA J.V., BLANCK T.J., RECIO-PINTO E. 2012. «A Role for the Cannabinoid 1 Receptor in Neuronal Differentiation of Adult Spinal Cord Progenitors in vitro is Revealed through Pharmacological Inhibition and Genetic Deletion». Front Neurosci, $6,4$.

[39] MULDER, J., AGUADO, T., KEIMPEMA, E., BARABÁS, K., BALLESTER ROSADO, C.J., NGUYEN, L., MONORY, K., MARSICANO, G., DI MARZO, V., HURD, Y.L., GUILLEMOT, F., MACKIE, K., LUTZ, B., GUZMÁN, M., LU, H.C., GALVE-ROPERH, I., HARKANY, T. 2008. «Endocannabinoid signaling controls pyramidal cell specification and longrange axon patterning». Proc Natl Acad Sci U S A, 105, 8760-8765.

[40] KEIMPEMA, E., BARABAS, K., MOROZOV, Y.M., TORTORIELLO, G., TORII, M., CAMERON, G., YANAGAWA, Y., WATANABE, M., MACKIE, K., HARKANY, T. 2010. «Differential subcellular recruitment of monoacylglycerol lipase generates spatial specificity of 2-arachidonoyl glycerol signaling during axonal pathfinding». J Neurosci, 30, 13992-14007.

[41] WU, C.S., ZHU, J., WAGER-MILLER, J., WANG, S., O'LEARY, D., MONORY, K., LUTZ, B., MACKIE, K., LU, H.C. 2010. «Requirement of cannabinoid $\mathrm{CB}(1)$ receptors in cortical pyramidal neurons for appropriate development of corticothalamic and thalamocortical projections». Eur $J$ Neurosci, 32, 693-706.

[42] OUDIN, M.J., HOBBS, C., DOHERTY, P. 2011. «DAGL-dependent endocannabinoid signalling: roles in axonal pathfinding, synaptic plasticity and adult neurogenesis». Eur J Neurosci, 34, 1634-1646.

[43] ZHOU, Y., OUDIN, M.J., GAJENDRA, S., SONEGO, M., FALENTA, K., WILLIAMS, G., LALLI, G., DOHERTY, P. 2015. «Regional effects of endocannabinoid, BDNF and FGF receptor signalling on neuroblast motility and guidance along the rostral migratory stream». Mol Cell Neurosci, 64, 32-43. 
I. Buceta, I. Rico, J. Egaña, S. Achicallende, I. Terradillos, N. Puente, L. Reguero, N. Royo, I. Bonilla, A. Medrano, J. Mendizabal, S.M. Gómez, A. Ramos, I. Gerrikagoitia, P. Grandes, I. Elezgarai

[44] BEGBIE, J., DOHERTY, P., GRAHAM, A. 2004. «Cannabinoid receptor, $\mathrm{CB} 1$, expression follows neuronal differentiation in the early chick embryo». $J$ Anat, 205, 213-218.

[45] GALVE-ROPERH I., AGUADO T., RUEDA D., VELASCO G., GUZMÁN M. 2006. «Endocannabinoids: A New Family of Lipid Mediators Involved in the Regulation of Neural Cell Development». Current pharmaceutical design, 12, 2319-2325.

[46] WATSON, S., CHAMBERS, D., HOBBS, C., DOHERTY, P., GRAHAM, A. 2008. «The endocannabinoid receptor, CB1, is required for normal axonal growth and fasciculation». Mol Cell Neurosci, 38, 89-97.

[47] DÍAZ-ALONSO, J., GUZMÁN, M., GALVE-ROPERH, I. 2012. «Endocannabinoids via CB1 receptors act as neurogenic niche cues during cortical development». Phil Trans $R$ Soc B, 367, 3229-3241.

[48] GULYAS, A.I., CRAVATT, B.F., BRACEY, M.H., DINH, T.P., PIOMELLI, D., BOSCIA, F., FREUND, T.F. 2004. «Segregation of two endocannabinoidhydrolyzing enzymes into pre- and postsynaptic compartments in the rat hippocampus, cerebellum and amygdala». Eur J Neurosci, 20, 441-458.

[49] BIRAN,V., VERNEY, C., FERRIERO, D.M. 2012. «Perinatal cerebellar injury in human and animal models». Neurol Res Int, 858929.

[50] LUJÁN, R., ROBERTS, J.D., SHIGEMOTO, R., OHISHI, H., SOMOGYI, P. 1997. «Differential plasma membrane distribution of metabotropic glutamate receptors mGluR1 alpha, mGluR2 and mGluR5, relative to neurotransmitter release sites». J Chem Neuroanat, 13, 219-241.

[51] GUZMÁN, M., SÁNCHEZ, C., GALVE-ROPERH, I. 2001. «Control of the cell survival/death decision by cannabinoids». J Mol Med, 78, 613-625.

[52] BEGBIE, J., DOHERTY, P., GRAHAM, A. 2004. «Cannabinoid receptor, $\mathrm{CB} 1$, expression follows neuronal differentiation in the early chick embryo». $J$ Anat, 205, 213-218.

[53] FERNÁNDEZ-RUIZ, J., GÓMEZ, M., HERNÁNDEZ, M.L., DE MIGUEL, R., RAMOS, J.A., 2004. «Cannabinoids and gene expression during brain development». Neurotox Res, 6, 389-401.

[54] FRIDE, E., 2004. «The endocannabinoid - CB1 receptor system in pre- and postnatal life». Eur J Pharmacol, 500, 289-297.

[55] GALVE-ROPERH, I. AGUADO, T., RUEDA, D., VELASCO, G., GUZMÁN, M. 2006. «Endocannabinoids: a new family of lipid mediators involved in the regulation of neural cell development». Curr Pharm Des, 12, 2319-2325

[56] WILSON, R.I., NICOLL, R.A. 2001. «Endogenous cannabinoids mediate retrograde signalling at hippocampal synapses». Nature, 410, 588-592

[57] WILSON, R.I., NICOLL, R.A. 2002. «Endocannabinoid signaling in the brain». Science, 296, 678-682.

[58] FREUND, T.F. KATONA, I., PIOMELLI, D. 2003. «Role of endogenous cannabinoids in synaptic signaling». Physiol Rev, 83, 1017-1066

[59] MACKIE, K. 2006. «Cannabinoid receptors as therapeutic targets». Annu Rev Pharmacol Toxicol, 46, 101-122. 
[60] OUDIN, M.J., HOBBS, C., DOHERTY, P. 2011. «DAGL-dependent endocannabinoid signalling: roles in axonal pathfinding, synaptic plasticity and adult neurogenesis». Eur J Neurosci, 34, 1634-1646.

[61] KAWAMURA, Y., FUKAYA, M., MAEJIMA, T., YOSHIDA, T., MIURA, E., WATANABE, M., OHNO-SHOSAKU, T., KANO, M. 2006. «The CB1 cannabinoid receptor is the major cannabinoid receptor at excitatory presynaptic sites in the hippocampus and cerebellum». J Neurosci, 26, 2991-3001.

[62] YOSHIDA, T., FUKAYA, M., UCHIGASHIMA, M., MIURA, E., KAMIYA, H., KANO, M., WATANABE, M. 2006. «Localization of diacylglycerol lipase-alpha around postsynaptic spine suggests close proximity between production site of an endocannabinoid, 2-arachidonoyl-glycerol, and presynaptic cannabinoid CB1 receptor». J Neurosci, 26, 4740-4751.

[63] ARGAW, A., DUFF, G., ZABOURI, N., CECYRE, B., CHAINE, N., CHERIF, H., TEA, N., LUTZ, B., PTITO, M., BOUCHARD, J.F. 2011. «Concerted action of CB1 cannabinoid receptor and deleted in colorectal cancer in axon guidance». J Neurosci, 31, 1489-1499.

[64] BLANKMAN, J.L., SIMON, G.M., CRAVATT, B.F. 2007. «A comprehensive profile of brain enzymes that hydrolyze the endocannabinoid 2-arachidonoylglycerol». Chem Biol, 14, 1347-1356.

[65] UCHIGASHIMA, M., YAMAZAKI, M., YAMASAKI, M., TANIMURA, A., SAKIMURA, K., KANO, M., WATANABE, M. 2011. «Molecular and morphological configuration for 2-arachidonoylglycerol-mediated retrograde signaling at mossy cell-granule cell synapses in the dentate gyrus». J. Neurosci, 31, 7700-7714.

[66] TANIMURA, A., UCHIGASHIMA, M., YAMAZAKI, M., UESAKA, N., MIKUNi, T., ABE, M., HASHIMOTO, K., WATANABE, M., SAKIMURA, K., KANO, M. 2012. «Synapse type-independent degradation of the endocannabinoid 2-arachidonoylglycerol after retrograde synaptic suppression». Proc Natl Acad Sci U S A, 109, 12195-12200.

[67] GÓMEZ, M., HERNÁNDEZ, M., JOHANSSON, B., DE MIGUEL, R., RAMOS, J.A., FERNÁNDEZ-RUIZ, J. 2003. «Prenatal cannabinoid and gene expression for neural adhesion molecule L1 in the fetal rat brain». Brain Res Dev Brain Res, 147, 201-207.

[68] CHANG, X., BIAN, Y., HE, Q., YAO, J., ZHU, J., WU, J., WANG, K., DUAN, T. 2017. «Suppression of STAT3 Signaling by $\Delta 9$ Tetrahydrocannabinol (THC) Induces Trophoblast Dysfunction». Cell Physiol Biochem, 42, 537-550.

[69] LAFUENTE, H., ALVAREZ, F.J., PAZOS, M.R., ALVAREZ, A., REYSANTANO, M.C., MIELGO, V., MURGIA-ESTEVE, X., HILARIO, E., MARTINEZ-ORGADO, J. 2011. «Cannabidiol reduces brain damage and improves functional recovery after acute hypoxia-ischemia in newborn pigs». Pediatric Research, 70, 272-277. 
I. Buceta, I. Rico, J. Egaña, S. Achicallende, I. Terradillos, N. Puente, L. Reguero, N. Royo, I. Bonilla, A. Medrano, J. Mendizabal, S.M. Gómez, A. Ramos, I. Gerrikagoitia, P. Grandes, I. Elezgarai

[70] PAZOS, M.R., CINQUINA, V., GÓMEZ, A., LAYUNTA, R., SANTOS, M., FERNÁNDEZ-RUIZ, J., MARTÍNEZ-ORGADO, J. 2012. «Cannabidiol administation after hipoxia-ischemia to newborn rats reduces long-term brain injury and restores neurobehabioral function». Neuropharmacology, 63, 776-783.

[71] DEVINSKY, O., CILIO, M.R., CROSS, H., FERNANDEZ-RUIZ, J., FRENCH, J., HILL, C., KATZ, R., DI MARZO, V., JUTRAS-ASWAD, D., NOTCUTT, W.G., MARTINEZ-ORGADO, J., ROBSON, P.J., ROHRBACK, B.G., THIELE, E., WHALLEY, B., FRIEDMAN, D. 2014. «Cannabidiol: pharmacology and potential therapeutic role in epilepsy and other neuropsychiatric disorders». Epilepsia, 55, 791-802.

[72] DEVINSKY, O., PATEL, A.D., THIELE, E.A., WONG, M.H., APPLETON, R., HARDEN, C.L., GREENWOOD, S., MORRISON, G., SOMMERVILLE, K. 2018. «Randomized, dose-ranging safety trial of cannabidiol in Dravet syndrome». Neurology, 90, e1204-e1211. 